\title{
Enzymatic Electrochemical Biosensor Based on Multiwall Carbon Nanotubes and Cerium Dioxide Nanoparticles for Rutin Detection
}

\author{
Stephen Rathinaraj Benjamin ${ }^{1,2}$, Ramon Silva Vilela ${ }^{1,3}$, Henrique Santiago de Camargo ${ }^{1}$, \\ Maria Izabel Florindo Guedes ${ }^{2}$, Katia Flavia Fernandes ${ }^{3}$, Flavio Colmati, ${ }^{1, *}$ \\ ${ }^{1}$ Laboratory of Bio-electrocatalysis and Fuel Cells (LABEL-FC), Instituto de Química, Universidade \\ Federal de Goiás, IQ-UFG, Av. Esperança, s n. 74690-900 Goiânia - GO, Brasil. \\ ${ }^{2}$ Grupo de Inovação Biotecnológica em Saúde, Laboratório de Biotecnologia e Biologia Molecular- \\ LBBM, Universidade Estadual do Ceará (UECE), Av. Paranjana, 1700 - Campus do Itaperi - 60714- \\ 903 Fortaleza - CE Brasil. \\ ${ }^{3}$ Laboratório de Química de Polímeros, Instituto de Ciências Biológicas, Departamento de Ciências \\ Físiológicas, Universidade Federal de Goiás (ICB-UFG), Av. Esperança, s n. 74690-900 Goiânia - \\ GO, Brasil. \\ *E-mail: colmati@ufg.br
}

doi: $10.20964 / 2018.01 .51$

Received: 1 October 2017 / Accepted: 10 November 2017 / Published: 16 December 2017

In this study, a simple and sensitive enzymatic electrochemical biosensor was developed to detect rutin by cyclic voltammetry (CV), differential pulse voltammetry (DPV) and square wave voltammetry (SWV) using a carbon paste electrode modified with a multiwall carbon nanotube (MWCNT), cerium oxide nanoparticle $\left(\mathrm{CeO}_{2}\right)$, and crude extract source of peroxidase enzyme (POx) composite. The electrochemical parameters and experimental conditions were optimized and evaluated. The enzymatic electrochemical biosensor (CeO2/POx/MWCNTs/CPE) showed excellent electrocatalytic activity towards the detection of rutin. The surface physical characteristics of the modified electrode were studied by scanning electron microscopy (SEM) and transmission electron microscopy (TEM). This biosensor demonstrated selectivity, stability, and reproducibility, which was further applied to detect rutin in medicine tablets and capsules with recoveries in the range of $97-102 \%$.

Keywords: Multiwall carbon nanotubes, Cerium dioxide nanoparticles, Crude extract, Rutin, POx.

\section{$\underline{\text { FULL TEXT }}$}

(C) 2018 The Authors. Published by ESG (www.electrochemsci.org). This article is an open access article distributed under the terms and conditions of the Creative Commons Attribution license (http://creativecommons.org/licenses/by/4.0/). 